\title{
Chemotherapy induced thrombocytopenia treated by four types of platelets concentrates
}

\author{
Ljubinka I. Nikolić ${ }^{1}$, Ninoslav D. Nedeljkovićn ${ }^{2}$ Svetislav B. Jelić ${ }^{2}$, \\ Nada D. Suvajdžić Vukovićs ${ }^{3}$ Ivana M. Fillipović-Lješković \\ Srdjan Z. Marković ${ }^{4}$, Drina Lj. Jankovićs ${ }^{\text {, Dragana A. Kastratović }}{ }^{4}$ \\ ${ }^{1}$ Clinic for Gynecology and Obstetrics, Clinical Centre of Serbia, Belgrade, Serbia \\ ${ }^{2}$ Institute for Oncology and Radiology of Serbia, Belgrade, Serbia \\ ${ }^{3}$ Clinic for Hemathology, Clinical Centre of Serbia, Belgrade, Serbia \\ ${ }^{4}$ Clinical Centre of Serbia, Belgrade, Serbia \\ ${ }^{5}$ Vinča Institute of Nuclear Sciences, Belgrade, Serbia
}

\section{SUMMARY}

Introduction: Serious adverse event of anticancer chemotherapy is glanulocytopenia and thrombocytopenia which can decrease efficiency of final therapy results. After many years, platelet concentrates transfusion (PCT) is still researching problem without sure standpoint.

The aim: To determine whether there is a difference in the clinical efficiency in the use of 4 types of platelet applied for transfusion; - to ascertain whether platelet count increase expressed as corrected count increment $(\mathrm{CCl})$, is a better parameter for the evaluation of platelet transfusion efficiency than the bleeding time (Bt), as the only readily assessable in vivo platelet function related parameter.

Subjects and methods: This paper is a part of academic (noncommercial) IV phase observational nointervetion study. Investigation included 78 patients diagnosed with malignant lymphoma and metastatic solid tumors, transfused by platelet concentrates. Patients were devided into 4 groups, based on the type of platelet concentrates used for transfusion.

Results: Patients, were transfused with total number of 647 PC units ( 235 units were non-leukodepleted and 412 units were leukodepleted). Mean number of PC transfusions per patient was 8.3 PC units, and 4.8 PC unit per one transfusion episode. Before PCT: platelets values were: $18.1 \times 10^{9} / \mathrm{L} \pm 13.1$, Bt $8.4 \pm 6.1 \mathrm{~min}$, and after PCT were 28.2 $\mathrm{x} 10^{9} / \mathrm{L} \pm 22.1,4.7 \pm 4.4$ min respectively $((\mathrm{p}<0.01)$. Mean $\mathrm{CCl}$ value was $13.8 \pm 30.4$. CCI was corrected in 196/129 PCT and Bt in 122/129 PCT. After supportive therapy using PCs Bt was corrected and became similar in all 4 goups.

Discussion: Clinical output is the most important parameter for treatment decision becouse many patients can tolerate prolonged periods of profound thrombocytopenia without serious bleeding problems.

Conclusion: In all 4 investigated groups of patients bleeding time was a far better parameter compared with $\mathrm{CCl}$ for the PC therapy efficency.

Authors sugest to be carrefull and follow clinical and laboratory results personalised to single patient. There is a need to develope better therapies and guidelines so the 
practice of platelet therapy can be expected to improve in the future.

Keywords: thrombocytopenia, cancer, platelet transfusion, bleeding

\section{INTRODUCTION}

Serious adverse event of anti cancer chemotherapy is glanulocytopenia and thrombocytopenia which can decrease efficiency of final therapy results.

The main complications of granulocytopenia is neutropenic sepsis, usually designed as febrile neutropenia. The consequences of leukopenia can be prevented in part of hospitalization in bacteriologically protected units and sterile box and profilactic usage of granulocate-collony stimulatinf factor (G-CSF) and granulocyte-macrophage colony stimalating factor (GM-CSF). Treatment includes a lot of available G-CSF and the CSFs.

Beside there are no such preventive measures and treatment facilities for thrombocytopenia which can result in life-threatening haemorrhagic syndrome, and platelet transfusion remains the only effective approach. Although both autologous bone marrow transplantation and periferal blood stem rescue have been advocated for high dose chemotherapy haematopoietic support, there is no doubt for importance platelet transfusions in the management of chemotherapy-related haematological toxicities in cancer patients.

Advances in platelet transfusion have contributed to improved outcomes in the treatment of cancer patients, allowing high dose chemotherapy delivery with increased safety $[1,2]$.

Continuous supportive platelet therapy is enabled by technological advancement and increased quality of plastic blood bags adjusted for prolonged platelet storage. However, concentrate-specific parameters can be influenced by preparation technique and storage procedures. The duration of storage causes increase of TGF level, which induces an impressive decrease in the in-vivo platelet recovery and survive $[3,4,5,6]$.

The benefits of prophylactic platelet transfusion are controversial and the circulating platelet level which predisposes to haemorrhage is unsertain; so is the effectiveness of alternatives to platelet therapy. Finally, the merits and drawbacks of treatment of thrombocytopenic patients with platelets from single donors and multiple random donors, need evaluations $[7,8]$.

Several serious scientists through the world after many years are still researching problem of platelet transfusion, but there is no for sure about standpoint $[9,10,11]$.

It has been shown by necessity that many patients can tolerate prolonged periods profound thrombocytopenia without serious problems. A two-fold (double) prolongation of the normal bleeding time, has been reported to be indicative of significant risk of bleeding [12].

\section{THE AIM}

To determine whether there is a difference in the clinical efficiency in the use of 4 types of platelet applied for transfusion; - to ascertain whether platelet count increase expressed as corrected count increment (CCI), is a better parameter for the evaluation of platelet transfusion efficiency than the bleeding time (Bt), as the only readily assessable in vivo platelet function related parameter.

\section{SUBJECTS AND METHODS}

This paper is a part of academic (noncommercial) IV phase observational nointervetion study, done at National Institute of Oncology and Radiology of Serbia (NIORS), Belgrade. All patients signed informed consent.

Because of technical problems this study was frozen, and this year problem was recognized again so these results are the first step of continuing ivestigating platelets charactreristics.

Clinical bleeding during chemotherapy-induced thrombocytopenia is a serious clinical problem. During several decades this serious citostatic adverse event is not solved and there is no doctrinar statement about this.

Cancer as itself disease is characterised with non stabile hemostatic parameters [13], so it is case to case clinical situation.

Investigation included 78 patients (34 males and 44 females), median age 57 years (range 23-73), diagnosed with limphoma and metastatic solid tumors, transfused by platelet 
concentrates from January till May 1998. None of the patients had disseminated intravascular coagulation (DIC), wide spread adenocarcinoma, infection, or other special situation or diagnosuis that might have influenced the outcome of platelet support.

The standards for research laboratories procedures, and investigator were met the required criteria.

Patients were devided into 4 groups, based on the type of platelet concentrates used for transfusion, and produced in Serbian National Blood Transfusion Institute (SNBTI). Four types of platelet concentates were used depending on Institute supply by the producer.

Group A - patients transfused with leucode- pleted platelet concentrates (PC) pool obtained from 5 platelet rich plasma PC units (PRP PC) $\mathrm{ABO}$ identical, or from 5 buffy coat PC units (BC PC) ABO identical (Leukotrap pooling system $^{\oplus}$, Cutter USA)

Gropu B - patients transfused with prestorage filtered PRP PC or BCPC using fourth generation filters (Terumo, Japan)

Group C - patients transfused with standard non-leukodepleted PC (PRP-PC stored 0-5 days) (plastic bags Terumo, Japan) on horizontal shaker at $22^{\circ} \mathrm{C}$

Group D - patients transfused with prestorage leukodepleted PC obtained from random donors $\mathrm{BC}$, using spontaneus sedimentation of verticaly positioned and stored BCs for 12 hours at $22^{\circ} \mathrm{C}$.

\begin{tabular}{|clccc|}
\multicolumn{1}{c}{ Type of PC } & Lymphoma & MST & N \\
\hline Patients group & \multicolumn{1}{c}{ Leukodepleted PC pool } & 3 & 24 & 27 \\
B & Leukodepleted prestorage filtered PC & 1 & 6 & 7 \\
C & Non-leukodepleted PC from random donors & 5 & 28 & 33 \\
D & Leukodepleted PC by spontaneous sedimentation & - & 11 & 11 \\
& Total & 9 & 69 & 78
\end{tabular}

In group $\mathrm{A}$ there were 3 patients whith limphoma and 24 with metastatic solid tumors; In group B there was one patients with limphoma and 6 patients with metastatic solid tumors; In group C there were 5 patients with limphoma and 28 with metastatic solid tumors and , group D there were 11 patients with metastatic solid tumors. Thus, there were 9 patients with lymphoma and 69 with metastatic solid tumors. Thrombocytopenia in all those patients was serious adverse event (SAE), as consequence of needed aggressive chemotherapy.

Indication for platelet transfusion treatment were:

1. bleeding time prolonged in 108/129 transfusion (Bt $3.4 \mathrm{~min}-37 \mathrm{~min}$ );

2. when clinical manifestation of haemorrhagic syndrome there present in 2/129 transfusions; 3 . when bleeding time was normal but platelets already with $\mathrm{WHO}$ grade 4 toxicity range, tested daily expressed tendency towards decrease in 19/129 transfusions.

Out of 108 transfisions in patients with prolonged bleeding time, thrombocytopenia was grade 4 in 97 patients, grade 3 in 8 cases, grade 2 in 2 cases and grade 1 in 1 case.

None of patients had DIC. Grading of thrombocytopenia was performed according to CTC criteria [14].
Efficiency of supportive therapy using PC transfusions was estimated according both to CCI and Duke test for bleeding time (BT) (reference values1 - 3 minutes), not traumatic

\begin{tabular}{lcc}
\multicolumn{1}{c}{$\begin{array}{c}\text { Transfusion } \\
\text { indication }\end{array}$} & $\begin{array}{c}\text { No of pts with } \\
\text { prolonged BT }\end{array}$ & $\begin{array}{c}\text { No of platelet } \\
\text { transfusions }\end{array}$ \\
$\begin{array}{l}\text { Prolonged } \\
\text { bleeding time }\end{array}$ & 108 & 129 \\
$\begin{array}{l}\text { Clinical } \\
\text { bleeding }\end{array}$ & 2 & 129 \\
$\begin{array}{l}\text { Decreased } \\
\text { Tendency of plt }\end{array}$ & 19 & 129
\end{tabular}

as Ivy test. BT and platelet count there were controlled before PC therapy and 20-24 hours after PC transfusion. BT was performed by the same tehnician although not highly precise technique, was chosen as the only test which evaluates in vivo platelet haemostatic function [15]. Tests were performed 20-24 hours after transfusion since platelet functinons are restored during that interval, reflecting clinical effect/benefit of a platelet transfusion. Our presumption was that this could be achieved only by using an in vivo platelet function test or by observing disappearence of clinical manifestations typical for thrombocytopenia.

Platelets were determined using automatic counter Cell Dyn 3500 (Abbott)
Table 1. Patients groups $(A, B, C, D)$ accordig to transfused paltelets

PC-platelet concentrate, MST-metastatic solid tumor

Table 2. Indication for platelet transfusion 
oobtained from blood specimens using the EDTA. Platelet values were repeated using the sodium citrate and the counting was carried out microscopically in chamber with the $1 \%$ ammonium oxalate.

Platelet count was not tested in our patients $1 \mathrm{~h}$ after PC transfusion because in that interval only data concernic total number of transfused platelet particles can be obtained. Storage platelets loose viability, decrease 2,3diphosphoglycerate (2,3 DPG), but can be acceptable as compromise during storage [16]. Around 20-24 hours after transfusion, removal of damaged platelets occurs, and energetic balance of platelets which have lost their energetic balance during storage is restored.

CCI was determined using the folloing formula:

$\mathrm{CCI}=\left(\left(\right.\right.$ post transfusion platelet count $\left(\mathrm{x} 10^{9} /\right.$ L)-pretranfusion platelet count $\left.\left(\mathrm{m}^{2}\right)\right) /$ total number platelets transfused

It is generally accepted that an effective PC treatment corresponds to a CCI after $24 \mathrm{~h}$ which is $\geq 4.5$.; for the purpose of this study we have considered as effective any CCI over zero $(>0)$ i.e. any platelet increase its relation to pretransfusion one. A corected bleeding time was considered any shorthening below 6 minutes if initial bleeding time was over 6

Table 3. Main patient characteristics and diagnosis

Pts-patients,

PC-platelet concentrates, Group A-leukodepleted pool of 6 random donor platelets, Group B-prestorage filtered PC, Group C-nonleukodepleted PC from random donor platelets, Group D-PC leukodepledet after spontaneous sedimentation.

\begin{tabular}{|c|c|}
\hline Characteristics & $\mathrm{N}(\%)$ \\
\hline Total number of patients & $78(100)$ \\
\hline \multicolumn{2}{|c|}{ Age (years) } \\
\hline Median & 57 \\
\hline Range & $23-73$ \\
\hline \multicolumn{2}{|c|}{ Sex } \\
\hline Male & $34(44)$ \\
\hline Female & $44(56)$ \\
\hline \multicolumn{2}{|c|}{ Diagnosis } \\
\hline Malignant lymphoma & $9(12)$ \\
\hline Metastatic solid tumors & $69(88)$ \\
\hline \multicolumn{2}{|c|}{ Group of pts according to type of PC } \\
\hline Group A & $27(34)$ \\
\hline Group B & 7 (9) \\
\hline Group C & $33(43)$ \\
\hline Group D & $11(14)$ \\
\hline \multicolumn{2}{|c|}{ Number of pts transfused with } \\
\hline Non leukodepleted PC & $33(41)$ \\
\hline Leukodepleted PC & $45(59)$ \\
\hline Total number of PC units & $647(100)$ \\
\hline Non leukodepleted PC & $235(36.3)$ \\
\hline Leukodepleted PC & $412(63.7)$ \\
\hline
\end{tabular}

minutes; if initial bleeding time was 6 minutes or below any shorthening was considered as evidence for a corected bleeding time, meaning that clinical endpoints (i.e. bleedeing) are the most important method for evaluating effectiveness of PLT transfusions [17].

In addition on PC investigated patients were transfuzed with red blood cells (RBC) (concentrates), fresh frozen plasma (FFP) and cryoprecipitate (Cryo): in group A were transfused with RBC and 2 with FFP; in group B , 2 patients were transfused with RBC; in group $C, 10$ patients were transused with RBC; One of those 10 patients also receive cryo and another received RBC and FFP. In group D two patients RBC.

Statistical methods used in the investigation were Kruskal-Wallis, Mann Whitny and Wilcoxon Rank Sum W test.

\section{RESULTS}

The patient's characteristics are presented on table 1 . Out of 78 patients, $33(41 \%)$ were transfused with non-leukodepleted PC, and remaining 45 (59\%) with leukocyte depleted PC. Total number of 647 PC units were used. Out of 647 PC units, 235 units (36.3\%) were non-leukodepleted and 412 (63.7\%) units were leukodepleted. Patients were transfused with the total number of $129 \mathrm{PC}$ transfusions. Mean number of $\mathrm{PC}$ transfusions per patient was 8.3 PC units, and 4.8 PC unit per one transfusion (table 1).

The mean platelet count in the investigated patients prior to transfusion was $18.14 \pm 13.1 \times 10^{\%} / \mathrm{L}$, median $=15.8$; range $1.6-80$ $.0 \times 10^{9} / \mathrm{L}$. Platelet levels were: Group A $14.8 \pm$ $8.1 \times 10^{9} / \mathrm{L}$; Group B $23.1 \pm 11.6 \times 10^{9} / \mathrm{L}$; Group C $18.9 \pm 11.8 \times 10^{9} / \mathrm{L}$; Group D 26.7 $24.9 \times 10^{9} / \mathrm{L}$. According to platelet count, investigated groups were homogenous before PC transfusions ( $\mathrm{p}>0.05)$, while according to the BT before $\mathrm{PC}$ transfusion, those 4 groups were not homogenous $(\mathrm{p}<0.05)$, Prior to transfusions BT was 8.4 \pm 6.1 minute for all investigated patients. In group A, BT was $9.1 \pm 6.4$ minutes, in group B BT was $5.1 \pm 1.8$ minutes, in group C BT was $9.9 \pm 6.3$ and in group D BT was $4.2 \pm 3.2$ minutes.

After PC transfusions, platelet count increse significantly in the total of all investigated patients:

Group A: Results are showen in table 7. Platelet count was noted in a significantly lesser 


\begin{tabular}{ccccc} 
Group & $\begin{array}{c}\text { PLT Pretransfusins } \\
\times 10^{9} / \mathrm{L}\end{array}$ & $\begin{array}{c}\text { PLT Posttransfusins } \\
\mathrm{x} 10^{9} / \mathrm{L}\end{array}$ & $\begin{array}{c}\text { CCI Corrected Count } \\
\text { Increment }\end{array}$ & $\mathrm{P}$ value \\
\hline A & $14.8 \pm 8.1$ & $22.7 \pm 19.3$ & $13.4 \pm 34.8$ & $\mathrm{P}<0.05$ \\
B & $23.1 \pm 11.6$ & $21.9 \pm 7.7$ & $8.6 \pm 6.0$ & $\mathrm{p}>0.05$ \\
C & $18.9 \pm 11.8$ & $37.0 \pm 26.7$ & $16.0 \pm 30.0$ & $\mathrm{p}>0.05$ \\
D & $26.7 \pm 24.9$ & $27.4 \pm 15.5$ & $9.4 \pm 16.8$ & $\mathrm{p}>0.05$ \\
ALL groups & $18.14 \pm 13.1$ & $28.2 \pm 22.1$ & $13.8 \pm 30.4$ & $\mathrm{P}<0.01$
\end{tabular}

number of perfomed PC transfusions, 39/53 $(73.6 \%)$ in relation to the number of corected Bt, 49/53 (92.4\%) PC transfusions $(\mathrm{P}<0.001)$. Satisfactory efficiency of platelet transfusions, based either on CCI or BT wsa noted in 51/53 PC transfusions, i.e. in $96.2 \%$ of transfusions. In 14 transfusions (11 patients), there was no expected platelet count increase. Bt was cor- rected in 12 of those transfusions, and in 2 transfusions, neither platelet count increase occurred, nor the correction of Bt. One of thoase 2 patints was female with malignant schwanoma and another was a male patients with non-Hodgkin lymphoma. Both patients had a stisfactory platelet count increase CCI and corrected Bt after the second PC transfu-

\begin{tabular}{|cccc|} 
Group & $\begin{array}{c}\text { BT Pretransfusins } \\
\text { (minutes) }\end{array}$ & $\begin{array}{c}\text { BT Posttransfusins } \\
\text { (minutes) }\end{array}$ & $\mathrm{P}$ value \\
\hline A & $9.1 \pm 6.4$ & $4.9 \pm 3.7$ & $\mathrm{P}<0.01$ \\
\hline B & $5.1 \pm 1.8$ & $3.3 \pm 1.9$ & $\mathrm{P}<0.05$ \\
C & $9.9 \pm 6.3$ & $5.4 \pm 6.0$ & $\mathrm{P}<0.01$ \\
D & $4.2 \pm 3.2$ & $2.7 \pm 1.9$ & $\mathrm{P}<0.01$ \\
All groups & $8.4 \pm 6.1$ & $4.7 \pm 4.4$ & $\mathrm{P}<0.01$ \\
\hline
\end{tabular}

sions. Patient with malignant scwanoma was transfused was transfused with PC on 4 occasions and only one of those transfusions she had unsatisfactory therapeutic response. This patient received no other blood products. Patient with non Hodgkin lymphoma was transfuse with PC on two occcasions and after the second transfusion he achived a positive therapeutic response and received no other blood products. In one female patients urticaria was noted. This patient was transfused only with after which Bt was correctted, but not platelet count. Two days later, this patient included into group D and was transfused, preceded by that appropriate premedication, and showed satisfactory therapeutic response, both according to $\mathrm{CCI}$ and $\mathrm{Bt}$ (tabl 7).

Group B: In two female patients, platelet count was not increased, i.e. satisfactory CCI was not obtained, but Bt was corrected. One patients suffferd from malignant schwanoma and the other one from ovarian cancer. Non of them

\begin{tabular}{|c|c|c|c|}
\hline & $\begin{array}{l}\text { Group of leukodeplete } \\
n=45 / 78^{*}\end{array}$ & $\begin{array}{l}\text { Group of non-leukodepleted } \\
\qquad n=33 / 51\end{array}$ & Total $n=78 / 129$ \\
\hline $\begin{array}{l}\text { Platelets prior to transfusion } \\
\mathrm{X}_{ \pm} \mathrm{SD}\left(\mathrm{x} 10^{9} / \mathrm{L}\right) \\
\text { Median (range) }\end{array}$ & $\begin{array}{c}17.76 \pm 13.8 \\
16.0(1.8-80)\end{array}$ & $\begin{array}{c}18.9 \pm 11.8 \\
15.4(3.7-54.8)\end{array}$ & $\begin{array}{c}18.1 \pm 13.1 \\
15.8(1.6-80)\end{array}$ \\
\hline $\begin{array}{l}\text { Platelets post transfusion } \\
\mathrm{X} \pm \mathrm{SD}\left(\mathrm{x} 10^{9} / \mathrm{L}\right) \\
\text { Median (range) }\end{array}$ & $\begin{array}{c}23.4 \pm 17.5 \\
18.8(2.7-96.7)\end{array}$ & $\begin{array}{c}37.0 \pm 26.7 \\
29.0(3.4-109)\end{array}$ & $\begin{array}{c}28.2 \pm 22.1 \\
21.8(2.7-109)\end{array}$ \\
\hline $\mathrm{CCl}(\mathrm{X} \pm \mathrm{SD})$ & $12.2 \pm 30.7$ & $16.0 \pm 30.0$ & $13.8 \pm 30.4$ \\
\hline $\begin{array}{l}\text { Bt prior to transfusion } \\
\mathrm{X} \pm \mathrm{SD} \text { (min) } \\
\text { Median (range) }\end{array}$ & $\begin{array}{c}7.7 \pm 5.9 \\
7.0(0.75-32)\end{array}$ & $\begin{array}{c}9.9 \pm 6.3 \\
8.8(3.4-37)\end{array}$ & $\begin{array}{c}8.4 \pm 6.1 \\
7.4(0.8-32)\end{array}$ \\
\hline $\begin{array}{l}\text { Bt post transfusion } \\
\mathrm{X} \pm \mathrm{SD} \text { (min) } \\
\text { Median (range) }\end{array}$ & $\begin{array}{c}4.4 \pm 3.4 \\
3.5(0.7-14-5)\end{array}$ & $\begin{array}{c}5.4 \pm 6.0 \\
3.3(1-32)\end{array}$ & $\begin{array}{c}4.7 \pm 4.4 \\
3.4(0.7-32)\end{array}$ \\
\hline Corrected CCI (\%) & $59 / 78(75.6)$ & $47 / 51(92.1)$ & $106 / 129(82.1)$ \\
\hline Corrected Bt (\%) & $73 / 78(93.6)$ & $4951(96.1)$ & $122 / 129(94.5)$ \\
\hline
\end{tabular}

Table 6. Analysis of platelet transfusion efficiency (leukodepleted versus non-leukodepleted PC)

Table 5. Bleeding time before and after platelet transfusion

Table 4. Platelet counts before and after PC transfusion 
Table 7. Analysis of Platelet transfusion Efficiency

* No of patients/no of plt transfusions,

BT-bleeding time,

PC-platelet concentrate
.

Platelets prior to
transfusion

$X \pm S D\left(\times 10^{9} / L\right)$
Median (range)

$14.8 \pm 8.1$

$15.2(1.8-43.4)$

$23.1 \pm 11.6$

Group B

Group C

$\mathrm{n}=33 / 51^{*}$

Group D

$n=11 / 15^{*}$

Total

$\underset{n=27 / 53^{*}}{\operatorname{Group} A}$

$\mathrm{n}=7 / 10^{*}$

8(13.0-39.8)

$18.9 \pm 11.8$

$26.7 \pm 24.9$

$18.1 \pm 13.1$

Platelets post

transfusion

$\mathrm{X} \pm \mathrm{SD}\left(\mathrm{x} 10^{\circ} / \mathrm{L}\right)$

Median (range)

$22.7 \pm 19.3$

$21.9 \pm 7.7$

$15.4(3.7-54.8)$

$17.2(3.9-80)$

$15.8(1.6-80)$

$\mathrm{CCl}(\mathrm{X} \pm \mathrm{SD})$

$16.1(2.7-96.7)$

$21.1(11.9-32.7)$

$37.0 \pm 26.7$

$27.4 \pm 15.5$

$28.2 \pm 22.1$

Bt prior to

transfusion

$\mathrm{X} \pm \mathrm{SD}$ (min)

Median (range)

$13.4 \pm 34.8$

$8.6 \pm 6.0$

(3.4-109) 22.7 (6.2-53.1)

21.8(2.7-109)

Bt post
transfusion

$\mathrm{X} \pm \mathrm{SD}(\min )$

Median (range)

$9.1 \pm 6.4$

$5.1 \pm 1.8$

$16.0 \pm 30.0$

$9.4 \pm 16.8$

$13.8 \pm 30.4$

$8.2(0.8-32)$

$4.9(2.2-7.3)$

$9.9 \pm 6.3$

$4.2 \pm 3.2$

$8.4 \pm 6.1$

$8.8(3.4-37)$

$3.4(1-10)$

$7.4(0.8-32)$

Corrected $\mathrm{CCl}(\%)$

$4.9 \pm 3.7$

$3.3 \pm 1.9$

$3.8(7-14.5)$

$3.3(0.7-5.8)$

$5.4 \pm 6.0$

$2.7 \pm 1.9$

$4.7 \pm 4.4$

Corrected Bt (\%)

39/53(73.6)

$8 / 10(80)$

$3.3(1-32)$

$1.8(0.7-6.3)$

$3.4(0.7-32)$

49/53(92.4)

$10 / 10(100)$

$47 / 51(92.1)$

12/15(80)

106/129(82.1)

No of

uncorrected $\mathrm{CCl}$

No of

uncorrected $\mathrm{CCl}$

and corrected BT

$$
\begin{gathered}
\text { No of } \\
\text { uncorrected BT } \\
\text { No of uncorrect- } \\
\text { ed CCI\& BT }
\end{gathered}
$$

No of uncor-

rected $\mathrm{BT}$ and corrected $\mathrm{CCl}$

No of uncor-

rected $\mathrm{CCl}$ and/ or BT

Transfusion adverse reaction - urticarial

No of pts transfused with FFP

No of pts

transfused with

Cryoprecipitate

No of pts trans-

fused with RBC

No of PC units per group

No of transfusions

Mean No of PC units per transfusion

Mean No of transfusion per patient

Mean No of PC units per patient

\begin{abstract}
14
\end{abstract}
12

2

2

2

2

0

14

2

0

0

0

4

263

53

$4.8 \pm 1.1$

$5,6 \pm 1.1$

1.96

1.43

1.54

1.36

1.65

9.3

8.1

7.1

8.4

8.3 
received any other blood products. Based on CCI, 8/10 PC transfusions, and according to $\mathrm{Bt}$, all showed satisfactory response.

Group C: In 4 PC transfusions (4 patients) was not corrected 20-24 hors after the procedure, while platelet count had increased. CCI was satisfactory in 47/52 (92.1\%) and Bt was corrected in 49/51 (96.1\%) PC transfusions. According to CCI and/or Bt , PC transfusions gave satisfactory result in 51/51 (100\%) transfusions in group C. Bt before PC transfusion was $9.9 \pm 6.3 \mathrm{~min}$, median $=8.8$, range $3.4-37$ minutes. Bt was not corrected in one female patients with NHL and in one patient with testicular cancer. CCI was not satisfactory in the patient with NHL, who had increase platelet count and uncorrected Bt in previous PC transfusion, as well as in the patient with metastatic solid tumors (leiomyosarcoma of the uterus, in one with gastric cancer, and in one with ovarian cancer). In this group there were no immediate transfusions reactiones (tabl 7). Group D: In three PC transfusions given to 3 patients CCI was not corrected. In 2 of these 3 patients Bt was corected. One of those patients suffered from laryngeal cancer and another one had maligmant schwanoma (who was transfused one month earlier in group one with leukodepleted PC). Out of these 3 patients, in one patient (female) with metastatic cancer with unknown primary tumor localisation, neither platelet count was increased nor Bt corrected. Three days later, the patient was transfused with the same dose of pooled leukocyte depleted platelets with a satisfactory clinicaly haemostatic efffect, platelet count increase and corrected Bt Unsatisfactory response in the first use of PC remains unexplaned. Based on CCI, PC transfusions were efficient in 12/15 (80\%) PC transfusions, and according to $\mathrm{Bt}$ in 14/15 (93.3\%) transfusions (table 7).

Platelet count value before PC transfusion for the group of patients who were transfused with leukocyted depleted platelets (groups $\mathrm{A}+\mathrm{B}+\mathrm{D}$ ) was $17.76 \pm 13.79 \mathrm{x}$ $\mathrm{x} 10^{9} / \mathrm{L}$, median $=16.0$, ranhe $1.8-80 \times 10^{9} / \mathrm{L}$. Bt before PC transfusion was $7.66 \pm 5.93 \mathrm{~min}$, median=7.0, range 0.75-32 minutes. After PC transfusion, platelet count was 23.40 $\pm 17.48 \times 10^{9} / 1$, median $=18.80$ range $2.67-96.7$. $\mathrm{Bt}$ after PC transfusion was $4.38 \pm 3.42$ minutes, median $=3-54$, range $0.67-14.5$. CCI for groups $\mathrm{A}+\mathrm{B}+\mathrm{D}$ was $12.17 \pm 30.73$, median $=6.82$, range 0.26-76.20. Platelet count increase i.e. positive
CCI was found in 59/78 (75.6) transusions and corrected Bt in 73/78 (93.6\%) (tabl 7).

In total, a corected CCI was found for $106 / 129$ transfusions (82.1\%) and corrected $\mathrm{Bt}$ for $122 / 129$ (94.5\%) PC transfusions $(\mathrm{p}=0.002$ tj $\mathrm{p}<0.01)$.

\section{DISCUSSION}

The investigated 4 groups were homogenous before platelet transfusions according to platelet count ( $\mathrm{p}=0.4$ ) and not homogenous according to $\mathrm{Bt}(\mathrm{p}<0.01 \mathrm{tj} \mathrm{p}=0.006)$. After supportive therapy using PCs Bt was corrected and became similar in all 4 goups. Nonhomogenity among 4 groups dessappeared $(\mathrm{p}=0.44)$ which possibly pointed to the positive effects of supportive platelet therapy and successful therapeutic result. These results correllated with literature data $[3,7]$

Concerning platelet count and $\mathrm{Bt}$ of all investgated patient groups there were no significant correlation either before $(\rho=-0.08)$ ar after PC transfusions $(\rho=-0.16)$ [9].

Significant platelet increase was noted in group $A(p<0.05$ tj $\mathrm{p}=0.046)$ and group $C(p=0.0001)$, in patients transfused with leukodeplated platelets (groups $\mathrm{A}+\mathrm{B}+\mathrm{D})(\mathrm{p}<0.05$ $\mathrm{p}=0.0239)$, as well as in all patients together (groups $A+B+C+D)(p<0.00001)$. In groups $B$ and $\mathrm{D}$ the number of patients was small so that significance could not be determine, although the increase was noted.

Compared with group A, group C had significantly higher platelet count after PC transfusion ( $\mathrm{p}=0.0048)$, as well as a higher CCI compared with group A ( $\mathrm{p}=0.0248)$. According to post transfusion $\mathrm{Bt}$, groups $\mathrm{C}$ and $\mathrm{A}$ did not differ significantly $(\mathrm{p}=0.9694)$.

Groups threated with leukocyte depleted PC (groups A, B and D) and group threated with non-leukocyte depleted PC showed homogenity before transfusion both according to platelet count $(\mathrm{p}=0.8)$ an $\mathrm{Bt}$ $(\mathrm{p}=0.07)$.

Non-leukodepleted PC treated group (group C) compared with leukodepleted PC treated group $(\mathrm{A}+\mathrm{B}+\mathrm{D})$ showed significantly higher platelet count increase $(\mathrm{p}<0.01 \mathrm{tj} . \mathrm{p}=0.0082)$, and significantly higher CCI $(p<0.05 p=0.0139)$ after PC transfusion. Higher efficiency of non-leukodepleted PC could be explaned partly by the presence of plasma and leukocyte contents (PGE1, IL6) $[18,19,20,10]$, and partly by the loss of a 
population of platelets during leukodepletion procedure (in groups $\mathrm{A}, \mathrm{B}, \mathrm{D}$ ) and the loss of cytokines which take part in platelet function and viability maintenance. However nonleukodepleted platelets are not recomended if multiple plartelet transfusion are required, in order to decrease the exposure to alloantigens, i.e. in order to postpone alloimmunization and refractorines [21,22,23,24,11].

Despite of non-uniforme numeric results and wide diferences in types of malignat diseases, clinicaly transfusion therapy outcome was satisfactory which is in correlation literatures dates. After more than ten years there is still dillemas and litlle bit confusion rellated to recomended values of platelet increase, shortening bleeding time and clinical outcome $[9,13,21]$.

Bt after PC transfusiomn showed no statistical differece between the groups of leukodepleted and non-leukodepleted PC treated patients $(\mathrm{p}=0.61)$. Leukocyte presence in group $\mathrm{C}$ did not induce occurence of posttransfusion reaktions. One posttransfusion reaction occured in group A and could be explained by the reaction to plasma present in platelet supernatant [21].

BT were significantly corrected in all patient groups in relation with the BT prior to platelet transfusion $(\mathrm{p}<0.01)$.

In $23 \mathrm{PC}$ transfusions platelet count and CCI increase did not occur. Out of 23 PC transfusions with unsatisfactory CCI, 5 were performed in 5 males, and 18 in 13 female patients. None of the female patents was treated by any other blood product. Likewise, the only posttransfusion reaction occurred in a female patient. As all there females were uni or multiparous this could speculatively be explained by the contact with another antigenic system during pregnancy $[25,26]$.

In 20 out of $23 \mathrm{PC}$ transfusions where platelet increase did not occurre and satisfctory CCI was not achieved, BT was corrected. In all 4 investigated groups BT was corrected in significantly higher percentage of PC transfusions compared with CCI $(\mathrm{p}=0.002)$.

To improve efficiency of platelet transfusion in patients who develope refractoriness, and to prevent or delay the onset of refractoriness, the storage time should be shortened $[3,27,11]$; single donor platelets (SD PC) should be used whenever possible rather than standard PC [28,11]. Transfusion of high platelet doses increases the transfusion inter- val and can reduced the number of Platelet concentrates required by thrombocytopenic patients that significantly reducing donor exposure $[29,11]$. HLA an HPA-matched platelets [30,31]; or as an alternative HLA class I eluted platelets should be used for succesful treatment of platelet transfusion refractoriness [32]. Washed platelet concentrates in patients with febrile non-haemolytic transfusion reactions should be used [33]. Autologous platelet transfusions are the best choice [34,11].

Disadvantages using profilactic PC therapy include increased number of donor exposures and possibly also enhanced risk of alloimmunzation and refractorines $[35,36,10,11]$. The advantages of profilactic therapy are still not universaly accepted.

Even when the value of prophylactic therapy is accepted the platelet count threshold at which this is justified is still very much a matter of debate and it is certainly true that not all patients with severe thrombocytopenia should be considered autothomatic candidates for prophylactic therapy $[37,38,39]$.

Since, many patients can tolerate prolonged periods of profound thrombocytopenia without serious bleeding problems $[10,11]$, bleeding time is much better parameter to assess (for assessement) the need for platelet transfusions than platelet level.

Platelet transfusion practice is being questioned more than ever before. As we develop better therapies and guidelines, the practice of platelet therapy can be expected to change in the near future $[10,11]$.

\section{CONCLUSION}

The advantages of profilactic PC therapy are not still universaly accepted, but authors agree with other published papers, that prophilactic platelet transfusion is clinicaly recommended.

Advantages using profilactic PC therapy include expenses preventing further costs of bleeding complications. Disadvantages are increased number of donor exposures and possibly also enhanced risk of alloimmunization.

These data show that beside PC therapy efficiency monitoring, which includes platelet counts and CCI, Bt in vivo platelet function test should also be performed. Since bleeding time was corrected in cases of uncorrected CCI, uncorrected CCI should not be considered as refractorines to PC without the deter- 
mination of bleeding time. PC transfusions followed by a satisfactory CCI but uncorrected Bt associated with clinical imrovement failed should not be considered as successful ones.

In all 4 investigated groups of patients bleeding time was a far better parameter compared with CCI for the PC therapy efficency . Bleeding time is much better parameter than platelet level for assessement the need for platelet transfusions.

Considering to cancer disease ethiology, course of disease, and patient clinical status in this sofisticated part of treatment success, it is necessery to assese clinical cost benefit results in any patient separetly.

Authors sugest to be carrefull and follow clinical and laboratory results personalised to single patient.

There is a need to develope better therapies and guidelines so the practice of platelet therapy can be expected to improve in the future. In the next part of this investigation we shall underline personalized medical treatment.

\section{ACKNOWLEDGMENTS}

Irena Vukajlović for technical assistace.

\section{REFERENCES}

1. Sarkodee-Adoo C, Schiffer CA Platelet transfusion support for patients with cancer and hematologic malignancies, Curr Opin Hematol (1996). 3(5):347-354

2. Hashiguchi $Y$, Fukuda T, Yoshida $H$, Ichimura $T$, Matsumoto $Y$, Yasui T, Sumi T, Ishiko O. Platelet transfusion during chemotherapy-induced thrombocytopenia in patients with gynecologic malignancy. Ann Oncol (2013) 24 (suppl 9): ix84.doi: 10.1093/ annonc/mdt460.91 11th Annual Meeting of the Japanese Society of Medical Oncology, 29-31 August 2013, Sendai, Japan. Abstract P2

3. Bock M., Muggenthaler K.H., Schmidt U., Heim M.U., Mempel W (1995). Post-transfusion rise in thrombocytes: observations in a hematologic-oncologic patient sample, Infusions ther Transfusions Med 22(6): 350-354

4. Rebulla P. Platelet Refractoriness. European Hematology Review, 2007;1(1):21-2

5. Goodnough, L.T., Riddell, J., Lazarus, H. et al. Prevalence of platelet transfusion reactions before and after implementation of leukocyte-depleted platelet concentrates by filtration. Vox Sang.1993; 65: 103-107

6. Goodnough, L. T., Maggio, P., Hadhazy, E., Shieh,
L., Hernandez-Boussard, T., Khari, P. and Shah, N. Restrictive blood transfusion practices are associated with improved patient outcomes. Transfusion, 2014; 54: 2753-2759.

7. Rebulla P. Platelet transfusion trigger in difficult patients. Transfus Clin Biol. 2001 Jun; 8(3):249-54.

8. Stanworth SJ. A No-Prophylaxis Platelet-Transfusion Strategy for Hematologic Cancers. The new England journal of medicine, may 9, 2013 vol. 368 no. 19

9. Vamvakas EC. Evidence-based practice of transfusion medicine: is it possible and what do the words mean? Transfus Med Rev. 2004; 18(4):267-78.

10. Vamvakas EC. Allogeneic blood transfusion and cancer recurrence: 20 years later. Transfusion. 2014; 54(9):2149-53.

11. Annen K, Olson JE. Optimizing platelet transfusions. Curr Opin Hematol. 2015 Nov; 22(6):559-64.

12. Schiffer CA. Hematological cancer: Prophylactic platelet transfusion is frequently not necessary $\mathrm{Na}$ ture Reviews Clinical Oncology 2013(10): 431-432

13. Djukić VB, Kastratović DA, Pendjer IP, Majstorović BM, Nikolić Ljl, Boricić IV, Vujicić ZN. Patient with double cancer--successfully treated. Acta Chir lugosl. 2005;52(3):91-3

14. Common toxicity Criteria. In: Investigator's Handbook. A manual for participants in clinical trials of investigational agents sponsored by the $\mathrm{Di}$ vision of Cancer Treatment, National Cancer Institute. NIH Pub 1993. 93-2770

15. Brinkhous KM. W. W. Duke and His Bleeding Time TestA Commentary on Platelet Function. JAMA. 1983; 250(9):1210-1214.

16. Thibault L, Beauséjour A, de Grandmont MJ, Lemieux R, Leblanc JF. Characterization of blood components prepared from whole-blood donations after a 24-hour hold with the platelet-rich plasma method Transfusion 2006 Aug;46(8):1292-9

17. Holbroa A, Infantia L, Sigleb J, Busera A. Platelet transfusion: basic aspect. Swiss med Wkly, 2013;143:w13885

18. Bishop J.F., Matthews J.P., Yaen K., McGrath K The definition of refractoriness to platelet transfusions. Transfusion Medicine. 1992;2:35-41

19. The Trial to Reduce Alloimmunization to Platelets Study Group (1997). Leukocyte reduction and ultraviolet B irradiation of platelets to prevent alloimmunization and refractoriness to platelet transfusions. N Engl J Med 1997; 337(26):1861-1869

20. Locker GJ, Staudinger T, Knapp S, Laczika KF, Burgmann H, Urlicic A. Wgner A, Metnitz P, Rnoebl P. Schuster E, Frass M. Prostaglandin El inhibits platelet decrease after massive blood transfusions during major surgery: influence on coagulation cascade?, J Trauma 1997. 42(3):525- 531 
21. Heddle NM, Klama L, Singer J, Richards C, Fedak P, Walker I, Kelton JG The role of the plasma from platelet concentrates in transfusion reactions, N Engl J Med. 1994.33I(10):625-628

22. Ishida A, Handa $M$ The efficacy of leukodepleted platelet transfusion, Nippon Rinsho. 1997, 55(9):2385-2391

23. Kunz D. Luley C, Heim MU, Bock M. Transforming growth factor beta is increased in plasma of patients with hematologic malignancies after transfusion of platelet concentrates, Transfusion 1998;38(2): 156-159

24. Seftel MD, Growe GH, Petraszko T, Benny WB, Le A, Lee CY, Spinelli JJ, Sutherland HJ, Tsang P, Hogge DE. Universal prestorage leukoreduction in Canada decreases platelet alloimmunization and refractoriness. Blood. 2004;103 (1): 333-339

25. Mollison PL, Engelfriet CP, Contreras M. The transfusion of platelets, leucocytes, hematopoietic cells and plasma components. In: Mollison's Blood Transfusion in Clinical Medicine. Oxford, Blackwell Scientific Publications, UK 11th edition, chapter 14; 2005: 611-665

26. Napier J.A.F. Handbook of Blood Transfusion Therapy. John Wiley\&Sons, Chichester, second edition, 1995: 75-94.

27. Duguid JK, Carr R, Jenkins JA, Hutton JL, Lucas GF, Davies JM. Clinical evaluation of the effects of storage time and irradiation on transfused platelets. Vox Sang. 1991; 60(3):151-4.

28. Anderson NA., Gray S., Copplestone JA., Chan DC., Hamon M., Prentice AG., Johnson SA., Philips M., van Waeg G., Oakhill A., Abeyasekera S., Pamphilon DH A prospective randomized study of three types of platelet concentrates in patients with hematological malignancy: corrected platelet count increments and frequency of nonhemolytic febrile transfusion reactions, Transfus Med, 1997;7(l):3339

29. Norol F, Bierling P, Roudot-Thoraval F, Le Coeur FF, Rieux C, Lavaux A, Kuentz M, Duedari N. Platelet transfusion: a dose-response study, Blood. 1998. 92(4): 1448-1453

30. Kekomaki S, Volin L, Koistinen P, KoivunenE, Koskimies S Ruutu T, Timonen T, Kekomaki R. Successful treatment of platelet transfusion refractoriness: the use of platelet transfusions matched for both human leucocyte antigens (HLA) and human platelet alloantigens (HPA) in alloimmunized patients with leukemia, Eur J Haematol. 1998. 60(2): 112-118

31. Meinke S, Sandgren P, Mörtberg A, Karlström C, Kadri N, Wikman A, Höglund P. Platelets made HLA deficient by acid treatment aggregate normally and escape destruction by complement and phagocytes in the presence of HLA antibodies. Transfusion. 2015 Oct 7. doi: 10.1111/trf.13350. [Epub ahead of print]
32. Novotny VM, Huizinga TW, van Doom R, Briet E, Brand A. HLA class I-eluted platelets as an alternative to HLA-matched platelets, Transfusion 1996. 36(5):438-444

33. MacWhannell A, Smith N, Thomas J (1999). The use of Washed Platelet Concentrates in Patients with febrile non-hemolytic transfusion Reactions, 11th MASCC International Symposium Supportive Care in Cancer Feb. 18-20, 150

34. Pedrazzoli P, Perotti C, Noris P, Da Prada GA, Zibera C, Battaglia M. Gibelli N, Preti P. Pavesi L, Torretta L, Balduini CL, Salvaneschi L, della Cuna GR. Autologous platelet transfusion in patients receiving high-dose chemotherapy and circulating progenitor cell transplantation for stage II/III brest cancer, Haematologica 1998. 83(8):718-23

35. Roy, A.J., Jaffe, N. and Djerassi, I. Prophylactic platelet transfusions in children with acute leukemia: a dose response study. Transfusion. 1973;13:283-290

36. Gmur, J., Burger, J., Schanz, U., Fehr, J. and Schaffner, A. Safety of stringent prophylactic platelet transfusion policy for patients with acute leukemia. Lancet. 1991. 338:1223-1226.

37. Seon Young Kim, Ji-Eun Kim, Hyun Kyung Kim, Kyou-Sup Han, Cheng Hock Toh.Accuracy of Platelet Counting by Automated Hematologic Analyzers in Acute Leukemia and Disseminated Intravascular Coagulation: Potential Effects of Platelet Activation. Am J Clin Pathol. 2010; 134(4):634-647.

38. Kunal Sehgal, Y. Badrinath, Prashant Tembhare, P. G. Subramanian, Sanjay Talole, Ashok Kumar, Vijaya Gadage, Shashikant Mahadik, Sitaram Ghogale, Sumeet Gujral. Comparison of Platelet Counts by CellDyn Sapphire (Abbot Diagnostics), LH750 (Beckman Coulter), ReaPanThrombo Immunoplatelet Method (ReaMetrix), and the International Flow Reference Method, in Thrombocytopenic Blood Samples. Cytometry Part B (Clinical Cytometry).2010; 78: 279-285.

39. Mishima Y, Tsuno NH, Matsuhashi M, Yoshizato T, Sato T, Ikeda T, et al. Effects of universal vs bedside leukoreductions on the alloimmunization to platelets and the platelet transfusion refractoriness. Transfus Apher Sci. 2014 Nov 11. [Medline] 


\title{
Upotreba četiri vrste koncentrata trombocita u tretmanu trombocitopenije izazvane hemioterapijom
}

\author{
Ljubinka I. Nikolić1, Ninoslav D. Nedeljković ${ }^{2}$ Svetislav B. Jelić 2 , \\ Drina Lj. Jankovićs , Dragana A. Kastratović ${ }^{4}$ \\ ${ }^{1}$ Klinika za ginekologiju i akušerstvo, Klinički centar Srbije, Beograd, Srbija \\ ${ }^{2}$ Institut za onkologiju i radiologiju Srbije, Beograd, Srbija \\ ${ }^{3}$ Klinika za hematologiju, Klinički centar Srbije, Beograd, Srbija \\ ${ }^{4}$ Klinički centar Srbije, Beograd, Srbija \\ ${ }^{5}$ Institut za nuklearne nauke Vinča, Beograd, Srbija
} Nada D. Suvajdžić Vuković3 , Ivana M. Fillipović-Lješković², Srdjan Z. Marković4,

\section{KRATAK SADRŽAJ}

Uvod: Ozbiljni neželjeni efekti antikancerske hemioterapije su granulocitopenija i trombocitopenija, koje mogu smanjiti efikasnost u konačnom ishodu terapije.

Nakon više godina transfuzija koncentratima trombocita (PCT) je još uvek predmet istraživanja bez sigurnih preporuka.

Cilj: Determinisati da li postoji razlika u kliničkoj efikasnosti ukoliko se za transfuziju koriste 4 tipa koncentrata trombocita $(P C)$; - proceniti da li je porast broja trombocita, izražen kao korigovani porast broja trombocita $(\mathrm{CCl})$, bolji parametar za procenu efikasnosti transfuzije trombocita od vremena krvarenja (Bt) kao jedinog testa za procenu funkcije trombocita in vivo.

Materija i metode: Ovaj rad je deo IV faze akademske (nekomercijalne) opservacione neinterventne studije. $U$ istraživanje je uključeno 78 pacijenata sa dijagnozom malignog limfoma i metastaskim solidnim tumorima koji su transfundovani koncentratima trombocita. Pacijenti su, na osnovu vrste trombocitnih koncentrata korišćenih za transfuziju, podeljeni u 4 grupe.

Rezultati: Za transfuziju ispitivanih pacijenta je korišćeno ukupno 647 jedinica PC od čega je 412 jedinica bilo osiromašeno leukocitima, a 235 nije. Prosečno je korišćeno 8.3 jednice PC po pacijentu i 4.8 PC jedinica za jednu transfuziju.

Pre PCT: vrednosti trombocita su bile: $18.1 \times 10^{9} / \mathrm{L} \pm 13.1$, Bt $8.4 \pm 6.1 \mathrm{~min}$, a nakon transfuzije $28.2 \times 10^{9} / \mathrm{L} \pm 22.1,4.7 \pm 4.4 \mathrm{~min}$ respektivno $((\mathrm{p}<0.01)$. Srednja vrednost $\mathrm{CCl}$ je bila 13.8 \pm 30.4 . CCl je bio korigovan u 196/129 PCT, a Bt u 122/129 PCT. Nakon suportivne terapije koncentratima trombocita vreme krvarenja se korigovalo i nije bilo statistički značajne razlike među grupama ( $p>0.05)$.

Diskusija: S obzirom da mnogi pacijenti oboleli od malignih bolesti mogu da tolerišu prolongirane periode izražene trombocitopenije bez pojave ozbiljnih krvarenja, pri donošenju odluke za klinički tretman najznačajniji parametar je klinički ishod.

Zaključci: U sve 4 istraživane grupe pacijenata vreme krvarenja je bilo mnogo bolji parametar od $\mathrm{CCl}$ za procenu efikasnosti PC terapije. Autori sugerišu opreznost i redovni monitoring kliničkih i laboratorijskih rezultata u skladu sa postulatima personalizovanog tretmana. Neophodno je razvijati bolje terapijske pristupe i vodiče za kliničku terapijsku upotrebu koncentrata trombocita u neposrednoj budućnosti.

Ključne reči: trombocitopenija, kancer, transfuzija trombocita, krvarenje 